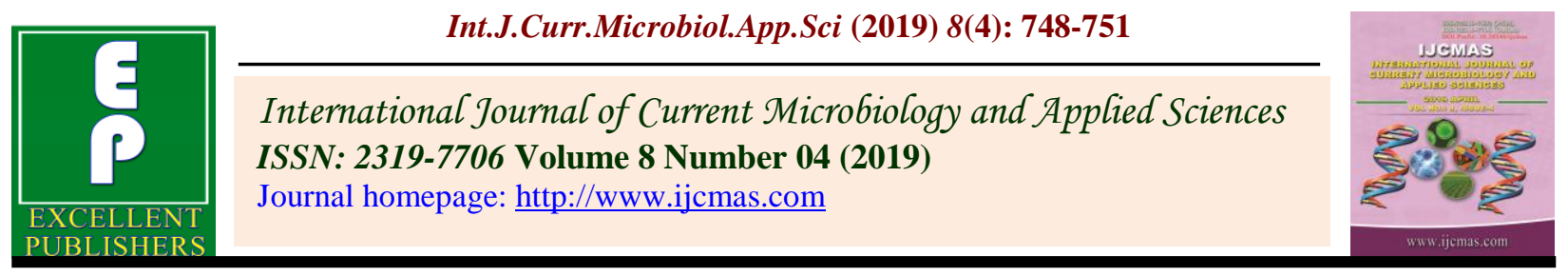

Original Research Article

https://doi.org/10.20546/ijcmas.2019.804.081

\title{
Performance of Frontline Demonstration on Yield Enhancement of Bajra in Barmer District of Rajasthan, India
}

\author{
Pradeep Pagaria*, L.R. Choudhary and Hari Dayal Choudhary \\ Krishi Vigyan Kendra, Gudamalani - Barmer (Rajasthan), India \\ *Corresponding author
}

\section{A B S T R A C T}

\begin{tabular}{|l|}
\hline Ke y w or d s \\
$\begin{array}{l}\text { Frontline } \\
\text { demonstration, } \\
\text { Yield enhancement } \\
\text { Bajra }\end{array}$ \\
\hline Article Info \\
\hline $\begin{array}{l}\text { Accepted: } \\
\text { 07 March } 2019 \\
\text { Available Online: } \\
\text { 10 April } 2019\end{array}$ \\
\hline
\end{tabular}

Keywords

Frontline

demonstration,

Yield enhancement

Bajra

Article Info

Accepted:

Available Online

10 April 2019

\section{Introduction}

Pearlmillet (Pennisetum typhoideum) is an important low value cereal crop grown in rainfed areas of country. The Indian hot arid zone is spread over $0.32 \mathrm{~m} \mathrm{~km}^{2}$ area and $65 \%$ of it is in the western district of Rajasthan. The climate induces frequent droughts, making arable cropping difficult and uncertain. Rajasthan has cultivated area of almost 20 million hectares but due to some unavoidable circumstances on $20 \%$ of the total cultivated area is irrigated. The economy of state is mostly depended on agriculture and 22.5 percent of state's GDP comes from agriculture. The Rajasthan is largest producer of pearlmillet in India. In Rajasthan it was grown on 5206162 ha with average productivity of $825 \mathrm{~kg} \mathrm{ha}^{-1}$ while in Barmer district it was grown on 1011401 ha with average productivity of $130 \mathrm{~kg} \mathrm{ha}^{-1}$ (Kharif 2008-09). The yield of pearlmillet crop is adversely affected by traditional cultivation without fertilizer application especially phosphatic fertilizer. This a good sign as bajra is scanty rainfall crop and it provides grain for humans and fodder for animals. Bajra had lowest yield of $7 \mathrm{~kg}$ per hectare in 2002-03

\section{Materials and Methods}

To increase the productivity of pearlmillet, 30 frontline demonstrations in 12 ha of land using hybrid MPMH 17 was conducted on farmer's field during 2018-19 in arid region of western Rajasthan to evaluate the 
economic feasibility of technology transfer and adoption via Front Line Demonstration with basic two objectives on speedy spread of the newly introduced HYV of Bajra and acquaint extension functionaries and local farmers with front line varietals and management technologies. The farmer's selection was made as per guidelines provided by ATARI Zone II to bridge the gap existing between state productivity and district productivity. The whole package approach demonstrated to farmers through FLD trials included component such as variety, seed rate, seed treatment, weed management and irrigation through sprinkler, fertilizers and plant protection measures. Under strict supervision of KVK scientists study was conducted from sowing to harvesting. Data on crop yield was recorded by per sq. meter observation method randomly from 3 to 4 places from an acre. Also side by side study was conducted from a random sample of 30 non demonstration farmers of Barmer districts. Thus the sample of the present study consisted of 60 respondent's farmers. The non-demonstration farmers were from the adjacent localities that joined in the pre seasonal training (kisan goshti) (whose names were registered on the day). The present study focused on changes in attitude, skill and knowledge level the recommended Bajra practices of the demonstration and nondemonstration farmers. Similar exercise was also made to measures the adoption score of the recommended practices. Data were collected personally by using pre -tested interview schedule from all respondent farmers (60). The attitude change in both categories of farmers was measured on three response categories (good, don't know and disagree) towards the FLD's programme. Skill performance was assessed on sowing of improved seeds and seed treatment by assigning one score each for those who followed the recommendations. The knowledge level of the recommended bajra practices was also determined by assigning one score for each correct answer and zero score for each wrong answer of the recommended practices viz. seed rate, seed treatment, sowing method, optimum spacing, correct doses of NPK fertilizers and time \& method of fertilizer application, diseases and pests management. The total scores assigned for all practices were II.

\section{Results and Discussion}

The study revealed that improved technology $\left(8.73 \mathrm{q} \mathrm{ha}^{-1}\right)$ registered 31.48 per cent increase in seed yield over the farmers practice $(6.64 \mathrm{q}$ $\left.\mathrm{ha}^{-1}\right)$. The most favorable one for pearlmillet when the highest yields of 11.2 and $7.4 \mathrm{qha}^{-1}$ in FLD and farmer's practice, respectively were recorded. It was evident from the yield levels recorded in demonstrations that the improved package of practices can boost the yield to the tune of even $3.80 \mathrm{qha}^{-1}$. These results confirm those obtained by conducting in FLD trials on various pulse crops (Das and Willey, 1991). Overall, the yield of demonstration plots exceeds that of farmer's plots in 21 FLD and 9 FLD failed due to drought only $111.3 \mathrm{~mm}$ rainfall. This was attributed to the quality seed used, adequate seed rate, management practices and judicious use of fertilizers. In terms of monitory return the net gain per hectare was Rs. 6660/- and was Rs. 45.6/- higher by investing additionally Rs. 400/-. With the improved package of practices fetch a higher B:C ratio of 2.23 while farmers practice gave 1.60 (Table 2).

The FLD produced a significant positive result on both the demonstration and nondemonstration farmers. 63 percent of demonstration farmers and 31 nondemonstration farmers were changed in their attitude towards the improved technology. This different in attitude change might be attributed to their frequent direct contact with 
the supervising scientist, Different extension activities like training programs, field days, practical demonstration on farmers' fields, frequent and regular field visits and contact supervising scientist at all important and critical stages of the crop, quick response on farmers request increased yields. Availability of the critical inputs like treated seeds, biofertilizers, fertilizers and plant protection chemical with sprayers were also another reason. The positive attitude gained by the non-demonstration farmers would be from the good results of the demonstration and participation to the field day programme at crop maturity stage (Table 1).

Table.1 Bajra area, production and productivity at Barmer District from year 2007-08 to $2016-17$

\begin{tabular}{|c|c|c|c|c|}
\hline S. No. & Year & Area(ha) & Production (tons) & Productivity (Kg/ha) \\
\hline $\mathbf{1}$ & $2007-08$ & 951949 & 164978 & 173 \\
\hline $\mathbf{2}$ & $2008-09$ & 1001934 & 129974 & 130 \\
\hline $\mathbf{3}$ & $2009-10$ & 956738 & 18402 & 19 \\
\hline $\mathbf{4}$ & $2010-11$ & 945072 & 529021 & 560 \\
\hline $\mathbf{5}$ & $2011-12$ & 867013 & 753021 & 469 \\
\hline $\mathbf{6}$ & $2012-13$ & 702042 & 295657 & 434 \\
\hline $\mathbf{7}$ & $2013-14$ & 851793 & 369471 & 275 \\
\hline $\mathbf{8}$ & $2014-15$ & 741051 & 203800 & 145 \\
\hline $\mathbf{9}$ & $2015-16$ & 767306 & 110980 & 150 \\
\hline $\mathbf{1 0}$ & $2016-17$ & 785162 & 117382 & 150 \\
\hline
\end{tabular}

*Source - Rajasthan Agricultural Statistics at a Glance, Govt. of Rajasthan

Table.2 Impact of improved technology on the economics of Bajra cultivation (Rs/ ha)

\begin{tabular}{|c|c|c|}
\hline S. No. & Particulars & Year 2009-10 \\
\hline \multirow[t]{3}{*}{1.} & \multicolumn{2}{|l|}{ Production cost } \\
\hline & Improved practice (IP) & 8170 \\
\hline & Farmers practice (FP) & 6852 \\
\hline 2 & Additional cost over FP & 1318 \\
\hline \multirow[t]{3}{*}{3} & \multicolumn{2}{|l|}{ Gross return } \\
\hline & IP & 13095 \\
\hline & FP & 9960 \\
\hline \multirow[t]{3}{*}{4} & \multicolumn{2}{|l|}{ Net return } \\
\hline & IP & 4925 \\
\hline & FP & 3108 \\
\hline \multirow[t]{3}{*}{5} & \multicolumn{2}{|l|}{ B:C ratio } \\
\hline & IP & 1.60 \\
\hline & FP & 1.45 \\
\hline 6 & Additional return & 1817 \\
\hline 7 & Increase in net return (\%) & 31.48 \\
\hline 8 & B:C on additional input in demonstration & 499 \\
\hline
\end{tabular}

IP- Improved practice; FP- Farmers practice 
From knowledge level point of view, the demonstration farmers had shown significantly higher scores than the nondemonstration farmers. Knowledge gains were higher by the demonstration farmers on the practices like seed rate, seed treatment, spacing and doses of fertilizers and IPM were only followed and noticed by the demonstration farmers.

The demonstrations influenced the adoption pattern of the recommended practices. The demonstration farmers had significantly higher score than the non demonstration farmers in the adoption of the recommended practices (Table 2 ).

Some of the major constraints reported by the demonstration and non-demonstration farmers were: timely non availability of plant protection chemicals, high cost of fertilizers, high incidence of pests and diseases and difficulty in getting improved seeds of HYV of Bajra.

FLD programme was effective in changing attitude, skill and knowledge of improved/recommended practices of HYV of Bajra including adoption. This also improved the relationship between farmers and scientist and built confidence between them. The demonstration farmers acted also as source of information and pure seeds for wider dissemination of the HYV of Bajra for other farmers.
The concepts of FLD may be applied to all farmers-categories including progressive farmers for speedy and wider dissemination of the recommended practices to other members of the farming community. This will help in the removal of the cross-sectional barrier of the farming population. Extension functionaries may be invited in the program to follow the same procedure in their future demonstration programme to achieve success.

\section{References}

Das, P. K. and Willey, R. W. 1991. A farmer's participatory approach to the development of improved, sustainable technologies for the resource- poor rainfed areas of the eastern plateau of India. Extension Strategies for Rainfed Agriculture. Ed. Indian Society of Extension Education. New Delhi, India pp. 199-205.

Hussain, M.M., Parigrahi, R and Ghosal, M.K. (1995). Extent of adoption constraints to the diffusion of farm and allied technology among farmers of Balipal block. Environment and Ecol, 13(2): 269-274.

Singh Narahari, Prasad Angad and Ram Daya (2005). Front line Demonstration on Rice Manipur. Agricultural extension Review. Pp.6-7.

Vital, Agriculture Statistics, 2016-17. Commissionaire of Agriculture, Govt. of Rajasthan.

\section{How to cite this article:}

Pradeep Pagaria, L.R. Choudhary and Hari Dayal Choudhary. 2019. Performance of Frontline Demonstration on Yield Enhancement of Bajra in Barmer District of Rajasthan, India. Int.J.Curr.Microbiol.App.Sci. 8(04): 748-751. doi: https://doi.org/10.20546/ijcmas.2019.804.081 